\title{
PENGARUH KETEBALAN PASIR DALAM SARINGAN PASIR DAN ARANG KAYU TERHADAP PENURUNAN KADAR BESI (FE), KEKERUHAN DAN WARNA AIR SUMUR GALI
}

\author{
Suprapto, TH.Teddy Bambang S, Mustar Rusli \\ Jurusan Kesehatan Lingkungan Poltekkes Kemenkes Medan
}

\begin{abstract}
Abstrak
Air minum yang mengandung besi $(\mathrm{Fe})$ cenderung menimbulkan rasa mual apabila dikonsumsi. Menurut Permenkes RI Nomor :416 / Menkes/Per/IX/1990 yang memenuhi syarat kadar maksimum yang diperbolehkan untuk zat besi $(\mathrm{Fe}$ ) pada air bersih : 1,0 mg/l, kekeruhan : $25 N T U$ dan warna : 50 $T C U$. Tujuan penelitian ini adalah untuk mengetahui pengaruh ketebalan pasir dalam saringan pasir dan arang kayu terhadap penurunan kadar besi $(F e)$,kekeruhan dan warna air sumur gali. Jenis penelitian ini adalah eksperimen dengan rancangan pre and postes control design. Sampel air sumur gali diambil dari Kelurahan Aur Medan Maimun sebanyak 100 liter. Pretest kadar besi $(\mathrm{Fe})$, kekeruhan dan warna sampel air sumur gali yaitu $1,20 \mathrm{mg} / \mathrm{l}, 18,13 \mathrm{NTU}$ dan 33,80 TCU . Postest yaitu hasil pengukuran kadar besi $(\mathrm{Fe})$, kekeruhan dan warna sampel air setelah air dialirkan sebanyak 3 liter pada saringan pasir dan arang kayu (pasir $\varnothing: 0,5-0,7 \mathrm{~mm}$ dan arang kayu $\varnothing: 0,5 \mathrm{~mm}-1,0$ $\mathrm{cm}$ ).Ketebalan pasir pertama $40 \mathrm{~cm}$ dan kedua $50 \mathrm{~cm}$ ). Kontrol menggunakan media saringan pasirkerikil,tebal pasir $60 \mathrm{~cm}$. Replikasi dilakukan sebanyak 8 (delapan) kali. Alat pengukuran kadar besi $(\mathrm{Fe})$, kekeruhan dan warna digunakan Spectrofotometer DR 2800. Analisa data dilakukan dari univariat, bivariat. Uji kenormalan dengan Kolongorov test, setelah data normal dilakukan uji $t$-test dan Anova dengan tingkat kepercayaan $(\alpha=0,05)$. Diperoleh ada pengaruh ketebalan pasir $40 \mathrm{~cm}, 50$ $\mathrm{cm}$ dalam media saringan pasir dan arang kayu terhadap penurunan kadar besi $(\mathrm{Fe})$, kekeruhan dan warna air sumur gali $\left(\mathrm{p}_{\text {-value }}=0,000<\alpha=0,05\right)$, ketebalan pasir $50 \mathrm{~cm}$ dalam media saringan pasir dapat menurunkan kadar besi $(\mathrm{Fe})$ sebesar $92,82 \%$. Masyarakat di kota Medan yang memiliki sumur gali yang airnya mengandung kadar besi $(F e)>1,0 \mathrm{mg} / \mathrm{l}$ dapat menggunakan media saringan pasir dan arang kayu dengan ketebalan pasir $50 \mathrm{~cm}$. Petugas Puskesmas dapat mensosialisasikan kepada masyarakat tentang media saringan pasir dan arang kayu dapat menurunkan kadar besi air sumur gali dengan ketebalan pasir $50 \mathrm{~cm}$
\end{abstract}

Kata Kunci : Ketebalan pasir, saringan, $(\mathrm{Fe})$, kekeruhan,warna

\section{Latar belakang masalah}

Air merupakan kebutuhan pokok bagi kehidupan, tanpa air yang tersedia yang cukup dan memenuhi syarat kehidupan di dunia tak dapat berlangsung.

Kebutuhan air yang pertama bagi terselenggaranya kesehatan yang baik adalah tersedianya air bersih yang memadai dari segi kuantitas dan kualitasnya yaitu memenuhi syarat fisik, kimia,mikrobiologik dan radioaktif. Menurut Permenkes RI Nomor :416 / Menkes/Per/IX/1990 yang memenuhi syarat fisik yaitu tidak berbau, jumlah zat padat terlarut (TDS) :1500 mg/l, kekeruhan : $25 \mathrm{NTU}$, tidak berasa, warna : 50 TCU. Syarat kimia yaitu tidak mengandung bahan kimia yang berbahaya (beracun) dan atau melebihi kadar maksimum yang diperbolehkan seperti zat besi $(\mathrm{Fe}): 1,0 \mathrm{mg} / \mathrm{l}$.

Berdasarkan Riskesdas (2013) pada saat ini prosentase rumah tangga di Indonesia yang memenuhi akses terhadap sumber air minum 66,8\%, pada umumnya pemakaian air per-orang/hari rumah tangga 50-99,9 liter
(28,3\%) dan 100-300 liter (40\%). Pada tahun $2010 \mathrm{di}$ Indonesia $27,9 \%$ rumah tangga masih menggunakan sumur gali. Pada sumur gali sering terdapat kadar besi $(\mathrm{Fe})$ yang tinggi. Hal ini akan dapat menimbulkan masalah dan kerugian pada manusia.

Air minum yang mengandung besi $(\mathrm{Fe})$ cenderung menimbulkan rasa mual apabila dikonsumsi. Selain itu dalam dosis besar dapat merusak dinding usus, rusaknya organ-organ penting seperti : pankreas, otot jantung dan ginjal. Sering kali kematian disebabkan kerusakan dinding usus ini. Kadar besi $(\mathrm{Fe}$ ) yang lebih dari $1,0 \mathrm{mg} / \mathrm{l}$ akan menyebabkan terjadinya iritasi pada mata dan kulit. Apabila kelarutan besi dalam air melebihi $10 \mathrm{mg} / \mathrm{l}$ air akan berbau seperti telur busuk, sangat tidak diinginkan oleh keperluan rumah tangga karena dapat menyebabkan bekas karat pada pakaian, porselen dan alat-alat lainnya (Slamet Juli Sumirat, 2004).

Berdasarkan hasil pemeriksaan laboratorium Balai Tehnik Kesehatan Lingkungan dan Pengendalian 
Penyakit (BTKLPP) Medan salah satu sampel air sumur gali kepala keluarga di Jalan Trikora Gang Bersatu Kecamatam Medan Denai kualitas airnya mengandung kadar besi $(\mathrm{Fe})$ tertinggi sebesar : 3,0 mg/l, dengan suhu : 24,5 ${ }^{\circ} \mathrm{C}$ dan $\mathrm{pH}: 7,5$ Pada umumnya masyarakat disana belum mendapatkan air minum dari Perusahaan Daerah Air Minum (PDAM) Tirtanadi Medan (Nainggolan Laris, 2013). Upaya untuk menurunkan kadar besi ( $\mathrm{Fe}$ ), kekeruhan dan warna air sumur gali ini, salah satu cara dapat dilakukan dengan menggunakan saringan pasir lambat (Slow sand filter) (BPPT,1999). Saringan pasir lambat adalah saringan yang menggunakan pasir sebagai media filter dengan ukuran butiran sangat kecil, namun mempunyai kandungan kuarsa yang tinggi. Proses filtrasi yang terjadi pada saringan pasir lambat, terjadi dengan memisahkan air dari kandungan kontaminan berupa partikel tersuspensi dan koloid, serta bakteri, dengan cara melewatkan air pada suatu media berpori. Pada prinsipnya material ini dapat berupa material apa saja, seperti lapisan granular pasir, batu yang dihancurkan, antrachite, kaca, sisa arang,dll. Pada prakteknya di lapangan, media berpori yang paling sering digunakan adalah pasir, karena pasir mudah ditemui dalam jumlah banyak, biaya yang murah, dan hasil pengolahan yang diberikan juga sangat memuaskan.

\section{Rumusan Masalah}

Bagaimana pengaruh ketebalan pasir dalam media saringan pasir dan arang kayu terhadap penurunan kadar besi $(\mathrm{Fe})$, kekeruhan dan warna pada air sumur gali?

\section{Tujuan Penelitian \\ Tujuan Umum}

Untuk mengetahui pengaruh ketebalan pasir dalam media saringan pasir dan arang kayu terhadap penurunan kadar besi $(\mathrm{Fe})$, kekeruhan dan warna pada air sumur gali.

\section{Tujuan Khusus.}

1. Untuk mengetahui pengaruh ketebalan pasir dalam media saringan pasir dan arang kayu setinggi $40 \mathrm{~cm}$, $50 \mathrm{~cm}$ terhadap penurunan kadar besi ( $\mathrm{Fe}$ ) pada air sumur gali.

2. Untuk mengetahui pengaruh ketebalan pasir dalam media saringan pasir dan arang kayu setinggi $40 \mathrm{~cm}$, $50 \mathrm{~cm}$ terhadap penurunan kadar kekeruhan pada air sumur gali.

3. Untuk mengetahui pengaruh ketebalan pasir dalam media saringan pasir dan arang kayu setinggi $40 \mathrm{~cm}$, $50 \mathrm{~cm}$ terhadap penurunan kadar warna pada air sumur gali.

\section{Hipotesa}

1. Ada pengaruh ketebalan pasir dalam media saringan pasir dan arang kayu setinggi $40 \mathrm{~cm}$ dan $50 \mathrm{~cm}$ terhadap penurunan kadar besi ( $\mathrm{Fe}$ ) pada air sumur gali.

2. Ada pengaruh ketebalan pasir dalam media saringan pasir dan arang kayu setinggi $40 \mathrm{~cm}$ dan $50 \mathrm{~cm}$ terhadap penurunan kadar kekeruhan pada air sumur gali.
3. Ada pengaruh ketebalan pasir dalam media saringan pasir dan arang kayu setinggi $40 \mathrm{~cm}$ dan $50 \mathrm{~cm}$ terhadap penurunan kadar warna pada air sumur gali.

\section{METODOLOGI PENELITIAN}

\section{Lokasi Penelitian}

Penelitian di laksanakan di ruang Laboratorium Poltekkes Kemenkes RI Medan Jl.Jamin Ginting Km 13,5 Kelurahan Lau Cih Kecamatan Medan Tuntungan Kota Medan.

\section{Waktu Penelitian}

Waktu penelitian ini dilaksanakan bulan Mei Agustus 2014.

\section{Desain Penelitian.}

Jenis penelitian ini adalah penelitian eksperimen yaitu mengetahui pengaruh ketebalan saringan pasir dan arang kayu terhadap penurunan kadar besi $(\mathrm{Fe})$, kekeruhan dan warna pada air sumur gali.

Desain penelitian ini menggunakan rancangan pre and postes control design. Replikasi yang dilakukan sebanyak 8 (delapan ) kali,berdasarkan rumus $(\mathrm{t}-1)(\mathrm{r}-1)$ $\geq 15$ ( Hannafiah,2003)

\section{Instrumen penelitian}

a. Meteran

b. Spectrofotometer DR 2800.

\section{Populasi dan Sampel.}

1. Populasi dalam penelitian ini adalah seluruh air sumur gali yang mengandung kadar besi $(\mathrm{Fe})$ yang tinggi ( > 1,0 mg/l ).

2. Sampel adalah sebahagian dari populasi yaitu diambil satu sumur gali yang hasil pemeriksaan kadar besi (Fe) airnya : 1,30 mg/l berlokasi di Jalan Brigjen Katamso dalam Kelurahan Aur Medan Maimun..

3. Teknik Pengambilan sampel.

Cara pemilihan sampel ialah dengan teknik purposive sampling, yaitu proses penarikan yang didasarkan suatu pertimbangan tertentu yang dibuat oleh peneliti sendiri yaitu :

a. Air sumur gali yang memiliki kadar $\mathrm{Fe}:>1,0$ $\mathrm{mg} / \mathrm{l}$

b. Air sumur gali keruh dan berwarna kuning.

c. Air sumur gali berlokasi di Jalan Brigjen Katamso dalam kelurahan Aur kota Medan.

d. Pengambilan sampel air sumur gali dilakukan pada pagi hari pukul $09.00-0.00 \mathrm{Wib}$.

\section{Teknik Pengumpulan Data}

1. Data Primer diperoleh dari hasil pemeriksaan kadar besi $(\mathrm{Fe})$, kekeruhan dan warna sebelum dan sesudah perlakuan.

2 Data Sekunder yang diambil adalah data gambaran daerah lokasi penelitian Air sumur gali. 


\section{Pengolahan Data}

Data yang terkumpul dari hasil pemeriksaan kadar besi $(\mathrm{Fe})$, kekeruhan dan warna air sumur gali sebelum dan sesudah penyaringan dengan menggunakan alat

Spectrofotometer DR 2800 baik terhadap kelompok perlakuan dan kontrol, kemudian ditabulasi, disajikan dalam bentuk tabel dan narasi.

\section{Analisa Data.}

Analisa data dilakukan dengan cara :

a. Univariat :yaitu data yang telah diolah ditabulasi dengan distribusi frekuensi dari masing-masing variabel yang diteliti. Prosentase penurunan dari masing-masing variabel dihitung dengan rumus : $\mathrm{a} / \mathrm{b} \times 100 \%$.

Keterangan : $\mathrm{a}=$ Penurunan kadar variabel setelah perlakuan

$\mathrm{b}=$ kadar awal variabel sebelum perlakuan.

b. Bivariat : data univariat di buat cross tabel antara ketebalan saringan pasir dan arang kayu dengan penurunan kadar besi $(\mathrm{Fe})$, kekeruhan dan warna air sumur gali sebelum perlakuan, kontrol dan sesudah perlakuan.

Uji kenormalan terlebih dahulu dilakukan dengan test Kosmogorov, setelah data yang diperoleh normal selanjutnya untuk melihat pengaruh ketebalan saringan pasir dan arang kayu dengan penurunan kadar besi $(\mathrm{Fe})$, kekeruhan dan warna air sumur gali dilakukan Uji t-test dependent.

Untuk melihat perbedaan ketebalan saringan pasir dan arang kayu terhadap penurunan kadar besi $(\mathrm{Fe})$, kekeruhan dan warna air sumur gali dilakukan uji Anova (Analisis of variance) apakah secara bermakna berpengaruh dengan tingkat level significancy atau pada $\alpha$ $=0,05$. Selanjutnya untuk melihat perbedaan dari masingmasing variabel dilanjutkan dengan menggunakan uji
"Tuckey-test". Analisis data penelitian dengan menggunakan bantuan komputerisasi.

\section{Hasil Penelitian}

Berdasarkan hasil pemeriksaan sampel air di Laboratorium Kementerian Kesehatan Balai Teknik Kesehatan Lingkungan dan Pengendalian Penyakit (BTKLPP) Kelas I Medan sebelum dan setelah penyaringan didapatkan hasil sebagai berikut :

\section{Analisis Univariat.}

\section{Kadar zat besi $(\mathrm{Fe})$, kekeruhan dan warna}

Tabel 1 terlihat bahwa rata-rata kadar besi $(\mathrm{Fe})$, air sumur gali sebelum melalui saringan pasir dan arang kayu pada kontrol, ketebalan pasir $40 \mathrm{~cm}$ dan $50 \mathrm{~cm}$ sebesar $1,20 \mathrm{mg} / \mathrm{l}$ dengan $\mathrm{SD}=0,0000$; rata-rata penurunan kadar besi $(\mathrm{Fe})$ sesudah perlakuan pada kontrol adalah $1,112 \mathrm{mg} / \mathrm{l}(92,70 \%)$ dengan $\mathrm{SD}=0,00463$, pada ketebalan pasir $50 \mathrm{~cm}$ adalah $1,113 \mathrm{mg} / \mathrm{l}(92,82 \%)$ dengan $\mathrm{SD}=0,00518$ dan pada ketebalan pasir $40 \mathrm{~cm}$ adalah 1,05 $\mathrm{mg} / \mathrm{l}(89,06 \%)$ dengan $\mathrm{SD}=0,0991$.

Selanjutnya rata-rata kekeruhan air sumur gali sebelum perlakuan adalah sebesar 18,13 NTU, $S D=$ 0,0000; dan rata-rata penurunan kekeruhan setelah perlakuan pada kontrol sebesar 12,00 NTU (66,19\%) dengan $\mathrm{SD}=0,02900$; pada ketebalan pasir $50 \mathrm{~cm}$ sebesar 4,63 NTU (25,53\%) dengan SD = 0,02295, serta ketebalan pasir $40 \mathrm{~cm}$ sebesar 5,29 NTU $(29,22 \%)$ dengan $\mathrm{SD}=$ 0,01188 .

Kemudian dilihat dari kadar warna air sumur gali sebelum melalui saringan pasir dan arang kayu rataratanya 33,80 TCU dengan $\mathrm{SD}=0,000$, setelah perlakuan rata-rata penurunan warna air sumur gali pada kontrol 11,10 TCU (32,84\%), dengan $\mathrm{SD}=0,1598$; ketebalan pasir $50 \mathrm{~cm}=9,69 \mathrm{TCU}(28,67 \%)$ dengan $\mathrm{SD}=0,01927$; dan ketebalan pasir $40 \mathrm{~cm}$ sebesar 6,13 TCU (18,13\%) dengan $\mathrm{SD}=0,05303$. Dapat dilihat pada tabel 1 berikut ini:

Tabel 1. Distribusi Frekuensi Prosentase penurunan kadar $F e$, kekeruhan dan warna air sumur gali sebelum dan sesudah melalui media saringan pasir dan arang kayu

\begin{tabular}{|c|c|c|c|c|c|c|c|c|c|c|c|}
\hline \multirow{2}{*}{ No. } & \multirow{2}{*}{ Var. } & \multirow{2}{*}{$\begin{array}{l}\text { Mean } \\
\text { Sebelum } \\
\text { Perlakuan }\end{array}$} & \multicolumn{9}{|c|}{ Rata-Rata penurunan setelah perlakuan } \\
\hline & & & Kontrol & $\%$ & SD & $50 \mathrm{~cm}$ & $\%$ & $\mathrm{SD}$ & $40 \mathrm{~cm}$ & $\%$ & $\mathrm{SD}$ \\
\hline 1. & $\operatorname{Besi}(F e)$ & $\begin{array}{c}1,20 \\
(\mathrm{mg} / \mathrm{l})\end{array}$ & 1,112 & 92,70 & 0,00463 & 1,113 & 92,82 & 0,00518 & 1,05 & 89,06 & 0,00991 \\
\hline 2. & $\begin{array}{l}\text { Kekeru- } \\
\text { han }\end{array}$ & $\begin{array}{l}\mathbf{1 8 , 1 3} \\
\text { (NTU) }\end{array}$ & 12,00 & 66,19 & 0,02900 & 4,63 & 25,53 & 0,02295 & 5,29 & 29,22 & 0,01188 \\
\hline 3. & Warna & $\begin{array}{l}\mathbf{3 3 , 8 0} \\
\text { (TCU) }\end{array}$ & 11,10 & 32,84 & 0,01598 & 9,69 & 28,67 & 0,01927 & 6,13 & 18,13 & 0,05303 \\
\hline
\end{tabular}

*) waktu kontak air seluruhnya sama ( 15 menit ). 


\section{Analisis Bivariat}

2. Pengaruh ketebalan pasir dalam saringan pasir dan arang kayu pada sampel air sumur gali dengan penurunan kadar Fe.

Tabel 2. Hasil uji beda rata-rata uji $t$-Test dependent kadar Fe,kekeruhan dan warna air sumur gali berdasarkan ketebalan pasir pada saringan pasir dan arang kayu

\begin{tabular}{|c|c|c|c|c|c|c|c|}
\hline \multirow[t]{2}{*}{$\begin{array}{l}\text { Ketebalan } \\
\text { Pasir }\end{array}$} & \multirow{2}{*}{$\begin{array}{l}\text { Rata-rata } \\
\text { kadar } F e \\
\text { sebelum } \\
\text { perlakuan }\end{array}$} & \multirow{2}{*}{$\begin{array}{l}\text { Rata-rata } \\
\text { kadar } F e \\
\text { sesudah } \\
\text { perlakuan }\end{array}$} & \multirow[t]{2}{*}{$\mathbf{t}$} & \multirow[t]{2}{*}{ Df } & \multirow[t]{2}{*}{$\mathbf{P}$} & \multicolumn{2}{|c|}{$\begin{array}{c}95 \% \text { Confidence } \\
\text { Interval of the DifFerence }\end{array}$} \\
\hline & & & & & & Lower & Upper \\
\hline Kontrol & & 0,0875 & 679,749 & & 0,000 & 1,10863 & 1,11637 \\
\hline $40 \mathrm{~cm}$ & & 0,1313 & 305,024 & & 0,000 & 1,06046 & 1,07704 \\
\hline $50 \mathrm{~cm}$ & 1,20 & 00863 & 608669 & 7 & 0000 & 110942 & 111808 \\
\hline
\end{tabular}

3. Pengaruh ketebalan pasir dalam saringan pasir dan arang kayu pada sampel air sumur gali dengan penurunan kadar kekeruhan.

Tabel 3. Hasil uji beda rata-rata uji $t$-Test Dependent Kadar kekeruhan berdasarkan ketebalan pasir pada saringan pasir dan arang kayu

\begin{tabular}{|c|c|c|c|c|c|c|c|}
\hline \multirow[t]{2}{*}{$\begin{array}{l}\text { Ketebalan } \\
\text { Pasir }\end{array}$} & \multirow[t]{2}{*}{$\begin{array}{l}\text { Mean } \\
\text { sebelum } \\
\text { perlakuan }\end{array}$} & \multirow[t]{2}{*}{$\begin{array}{l}\text { Mean } \\
\text { sesudah } \\
\text { perlakuan }\end{array}$} & \multirow[t]{2}{*}{$\mathbf{t}$} & \multirow[t]{2}{*}{ df } & \multirow[t]{2}{*}{$\begin{array}{c}\mathbf{p} \\
\text { value }\end{array}$} & \multicolumn{2}{|c|}{$\begin{array}{l}95 \% \text { Confidence } \\
\text { Interval of the Difference }\end{array}$} \\
\hline & & & & & & Lower & Upper \\
\hline Kontrol & & 6,1288 & 1170,456 & & 0,000 & 11,97700 & 12,02550 \\
\hline $40 \mathrm{~cm}$ & & 12,8438 & 1258,848 & & 0,000 & 5,27632 & 5,29618 \\
\hline $50 \mathrm{~cm}$ & 18,13 & 13,5013 & 570,416 & 7 & 0,000 & 4,60956 & 4,64794 \\
\hline
\end{tabular}

Berikut penjelasan dari tabel di atas, hasil uji $t$ Test Dependent pada tabel 2 diatas terlihat bahwa ada pengaruh ketebalan pasir baik pada kontrol $(60 \mathrm{~cm})$ dengan confidence level $(\alpha=5 \%)$ dapat diketahui $\mathrm{t}=679,749, \mathrm{df}=$ 7, dan nilai Probabilitas $=0,000(\mathrm{p}<\alpha=0,05)$ dengan interval confidence ( $1,10863-1,11637)$ yang berarti ada pengaruh perbedaan penurunan kadar $\mathrm{Fe}$ air sumur gali pada kontrol setelah melalui saringan pasir dan arang kayu. Pada ketebalan pasir $40 \mathrm{~cm}$ diketahui $\mathrm{t}=305,024, \mathrm{df}=7$, dan nilai Probabilitas $=0,000(\mathrm{p}<\alpha=0,05)$ dengan interval confidence $(1,06046-1,07704)$ yang berarti ada pengaruh perbedaan penurunan kadar $\mathrm{Fe}$ air sumur gali setelah melalui saringan pasir dan arang kayu. Demikian juga pada ketebalan pasir $50 \mathrm{~cm}$ diketahui $\mathrm{t}=608,669, \mathrm{df}=$ 7 , dan nilai Probabilitas $=0,000(\mathrm{p}<\alpha=0,05)$ dengan interval confidence $(1,10942-1,11088)$ yang berarti ada pengaruh perbedaan penurunan kadar $\mathrm{Fe}$ air sumur gali setelah melalui saringan pasir dan arang kayu.
Dari hasil uji $t$-Test Dependent pada tabel 3 diatas terlihat bahwa ada pengaruh ketebalan pasir baik pada kontrol $(60 \mathrm{~cm})$ dengan confidence level $(\alpha=5 \%)$ dapat diketahui $\mathrm{t}=1170,456$, df $=7$, dan nilai Probabilitas $=$ $0,000(\mathrm{p}<\alpha=0,05)$ dengan interval confidence ( $11,97700-12,02550)$ yang berarti ada pengaruh ketebalan pasir pada kontrol terhadap perbedaan penurunan kadar kekeruhan air sumur gali pada kontrol setelah melalui saringan pasir dan arang kayu. Pada ketebalan pasir $40 \mathrm{~cm}$ diketahui $\mathrm{t}=1258,848, \mathrm{df}=7$, dan nilai Probabilitas $=$ $0,000(\mathrm{p}<\alpha=0,05)$ dengan interval confidence ( $5,27632-5,29618)$ yang berarti ada pengaruh ketebalan pasir $40 \mathrm{~cm}$ terhadap perbedaan penurunan kadar kekeruhan air sumur gali setelah melalui saringan pasir dan arang kayu. Demikian juga pada ketebalan pasir $50 \mathrm{~cm}$ diketahui $\mathrm{t}=570,416$, $\mathrm{df}=7$, dan nilai Probabilitas $=$ $0,000$ ( $\mathrm{p}<\alpha=0,05)$ dengan interval confidence (4,60956-4,64794) yang berarti ada pengaruh ketebalan pasir $50 \mathrm{~cm}$ terhadap perbedaan penurunan kadar kekeruhan air sumur gali setelah melalui saringan pasir dan arang kayu. 
4. Pengaruh ketebalan pasir dalam saringan pasir dan arang kayu pada sampel air sumur gali dengan penurunan kadar warna.

Tabel 4. Hasil uji beda rata-rata uji t-Test Dependent kadar warna air sumur gali berdasarkan ketebalan pasir pada saringan pasir dan arang kayu

\begin{tabular}{|c|c|c|c|c|c|c|c|}
\hline \multirow[t]{2}{*}{$\begin{array}{l}\text { Ketebalan } \\
\text { Pasir }\end{array}$} & \multirow[t]{2}{*}{$\begin{array}{l}\text { Mean } \\
\text { sebelum } \\
\text { perlakuan }\end{array}$} & \multirow[t]{2}{*}{$\begin{array}{l}\text { Mean } \\
\text { sesudah } \\
\text { perlakuan }\end{array}$} & \multirow[t]{2}{*}{$\mathbf{t}$} & \multirow[t]{2}{*}{ Df } & \multirow[t]{2}{*}{$\begin{array}{c}\mathbf{p} \\
\text { value }\end{array}$} & \multicolumn{2}{|c|}{$\begin{array}{l}95 \% \text { Confidence } \\
\text { Interval of the DifFerence }\end{array}$} \\
\hline & & & & & & Lower & Upper \\
\hline Kontrol & & 22,7038 & 1964,026 & & 0,000 & 11,08289 & 11,10961 \\
\hline $40 \mathrm{~cm}$ & 33,80 & 27,6688 & 327,000 & & 0,000 & 6,08691 & 6,17559 \\
\hline $50 \mathrm{~cm}$ & & 24,1100 & 1422,103 & & 0,000 & 9,67389 & 9,70611 \\
\hline
\end{tabular}

Dari hasil uji $t$-Test Dependent pada tabel 4 diatas terlihat bahwa ada pengaruh ketebalan pasir baik pada kontrol $(60 \mathrm{~cm})$ dengan confidence level $(\alpha=5 \%)$ dapat diketahui $\mathrm{t}=1964,026$, $\mathrm{df}=7$, dan nilai Probabilitas $=$ $0,000(\mathrm{p}<\alpha=0,05)$ dengan interval confidence $(11,08289-11,10961)$ yang berarti ada pengaruh ketebalan pasir pada kontrol terhadap perbedaan penurunan kadar warna air sumur gali pada kontrol setelah melalui saringan pasir dan arang kayu. Pada ketebalan pasir $40 \mathrm{~cm}$ diketahui $\mathrm{t}=327,000, \mathrm{df}=7$, dan nilai Probabilitas $=$ $0,000(\mathrm{p}<\alpha=0,05)$ dengan interval confidence $(6,08691-$ $6,17559)$ yang berarti ada pengaruh ketebalan pasir $40 \mathrm{~cm}$ terhadap perbedaan penurunan kadar warna air sumur gali setelah melalui saringan pasir dan arang kayu. Demikian juga pada ketebalan pasir $50 \mathrm{~cm}$ diketahui $\mathrm{t}=1422,103 \mathrm{df}$ $=7$, dan nilai Probabilitas $=0,000(\mathrm{p}<\alpha=0,05)$ dengan interval confidence $(9,67389-9,70611)$ yang berarti ada pengaruh ketebalan pasir $50 \mathrm{~cm}$ terhadap perbedaan penurunan kadar warna air sumur gali setelah melalui saringan pasir dan arang kayu

Uji perbedaan pengaruh ketebalan pasir 1. Uji beda penurunan kadar besi ( $\mathrm{Fe}$ )

Tabel 5. Penurunan kadar besi $(\mathrm{Fe})$ air sumur gali pada perlakuan Terhadap masing-masing ketebalan pasir

\begin{tabular}{lccccc}
\hline & $\begin{array}{l}\text { Sum of } \\
\text { Squares }\end{array}$ & Df & $\begin{array}{l}\text { Mean } \\
\text { Square }\end{array}$ & F & Sig. \\
\hline Between & 0,011 & 2 & 0,005 & 107,646 & 0,000 \\
Groups & 0,001 & 21 & 0,000 & & \\
Within & 0,012 & 23 & & & \\
Group & & & & & \\
Total & & & & & \\
\hline
\end{tabular}

F-hitung pada uji Anova diatas adalah 107,646 dengan probabilitas yaitu 0,000 , karena $\alpha=0,05$, maka ada perbedaan pengaruh ketebalan pasir pada kontrol $(60 \mathrm{~cm})$, $40 \mathrm{~cm}$ dan $50 \mathrm{~cm}$ sebelum dan sesudah perlakuan terhadap penurunan kadar besi $(\mathrm{Fe})$ air sumur gali pada saringan pasir dan arang kayu.
Untuk melihat uji beda, selanjutnya pada tabel 6 dapat dilihat lebih jelas seperti pada hasil sebagai berikut :

Tabel 6. Uji beda ketebalan pasir terhadap penurunan kadar besi $(\mathrm{Fe})$ air sumur gali dalam saringan pasir dan arang kayu

\begin{tabular}{|c|c|c|c|c|c|c|}
\hline \multirow[t]{2}{*}{ (I) } & \multirow{2}{*}{$\begin{array}{l}\text { Ketebalan }(\mathbf{J}) \\
\text { Ketebalan } \\
\text { pasir pasir }\end{array}$} & \multirow{2}{*}{$\begin{array}{c}\text { Mean } \\
\text { DifFerence } \\
\text { (I-J) }\end{array}$} & \multirow[t]{2}{*}{ Std.Error } & \multirow[t]{2}{*}{ Sig. } & \multicolumn{2}{|c|}{$\begin{array}{l}95 \% \text { Confidence } \\
\text { Interval }\end{array}$} \\
\hline & & & & & Lower & Upper \\
\hline & ntrol $(K)(60 \mathrm{~cm})(40$ & $-0,04375 *$ & 0,00349 & 0,000 & $-0,0510$ & $-0,0365$ \\
\hline & $(50 \mathrm{~cm})$ & 0,00125 & 0,00349 & 0,724 & $-0,0060$ & 0,0085 \\
\hline & tebalan $(40 \mathrm{~cm}) \mathrm{K}(60$ & $0,04375 *$ & 0,00349 & 0,000 & 0,0365 & 0,0510 \\
\hline & $(50 \mathrm{~cm})$ & $0,04500 *$ & 0,00349 & 0,000 & 0,0377 & 0,0523 \\
\hline & tebalan $(50 \mathrm{~cm}) \mathrm{K}(60$ & $-0,00125$ & 0,00349 & 0,724 & $-0,0085$ & 0,0060 \\
\hline & $(40 \mathrm{~cm})$ & $-0,04500 *$ & 0,00349 & 0,000 & $-0,0523$ & $-0,0377$ \\
\hline
\end{tabular}

Terlihat pada tabel 6 uji beda pengaruh ketebalan pasir pada Kontrol $(60 \mathrm{~cm})$ dengan ketebalan pasir $(40 \mathrm{~cm})$ memiliki beda nyata penurunan kadar besi $(\mathrm{Fe})$ air sumur gali dengan nilai $\mathrm{p}_{\text {value }}=0,000<\alpha=0,05$, pada $95 \%$-CI ($0,0510-0,0365)$, dengan ketebalan pasir $(50 \mathrm{~cm})$ tidak memiliki beda nyata dengan nilai $\mathrm{p}_{\text {value }}=0,724>\alpha=0,05$, pada 95\%-CI (-0,0060-0,0085).

Perbedaan ketebalan pasir $(40 \mathrm{~cm})$ dengan Kontrol $(60 \mathrm{~cm})$ memiliki beda nyata penurunan kadar besi $(\mathrm{Fe})$ air sumur gali dengan nilai $\mathrm{p}_{\text {value }}=0,000<\alpha=0,05$, pada $95 \%$-CI $(0,0365-0,0510)$. Ketebalan pasir $(40 \mathrm{~cm})$ dengan ketebalan pasir $(50 \mathrm{~cm})$ juga memiliki beda nyata penurunan kadar besi $(\mathrm{Fe})$ dengan nilai $\mathrm{p}_{\text {value }}=0,000<\alpha=$ 0,05, pada 95\%-CI (0,0377-0,0523).

Perbedaan ketebalan pasir $(50 \mathrm{~cm})$ dengan Kontrol $(60 \mathrm{~cm})$ tidak memiliki beda nyata penurunan kadar besi $(\mathrm{Fe})$ air sumur gali dengan nilai $\mathrm{p}_{\text {value }}=0,724>\alpha$ $=0,05$, pada 95\%-CI $(0,0085-0,0060)$. Tetapi pada ketebalan pasir $(50 \mathrm{~cm})$ dengan ketebalan pasir $(40 \mathrm{~cm})$ memiliki beda nyata penurunan kadar besi $(\mathrm{Fe})$ dengan nilai $\mathrm{p}_{\text {value }}=0,000<\alpha=0,05$, pada $95 \%$-CI $(0,0523$ 0,0377). 


\section{Uji beda penurunan kadar kekeruhan}

Tabel 7. Penurunan kadar kekeruhan air sumur gali pada perlakuan Terhadap masing-masing ketebalan pasir

\begin{tabular}{llllll}
\hline & $\begin{array}{l}\text { Sum of } \\
\text { Squares }\end{array}$ & Df & $\begin{array}{l}\text { Mean } \\
\text { Square }\end{array}$ & F & Sig. \\
\hline Between & 266,339 & 2 & 133,170 & 264763,46 & 0,000 \\
Groups & 0,011 & 21 & 0,001 & & \\
$\begin{array}{l}\text { Within } \\
\text { Group }\end{array}$ & 266,350 & 23 & & & \\
Total & & & & & \\
\hline
\end{tabular}

F-hitung pada uji Anova diatas adalah 264763,46 dengan probabilitas yaitu 0,000 , karena $\alpha=0,05$, maka ada perbedaan pengaruh ketebalan pasir pada kontrol $(60 \mathrm{~cm})$, $40 \mathrm{~cm}$ dan $50 \mathrm{~cm}$ sebelum dan sesudah perlakuan terhadap penurunan kadar kekeruhan air sumur gali pada saringan pasir dan arang kayu.

Untuk melihat uji beda, selanjutnya pada tabel 8 dapat dilihat lebih jelas seperti pada hasil sebagai berikut :

Tabel 8. Uji beda ketebalan pasir terhadap penurunan kadar kekeruhan air sumur gali dalam saringan pasir dan arang kayu

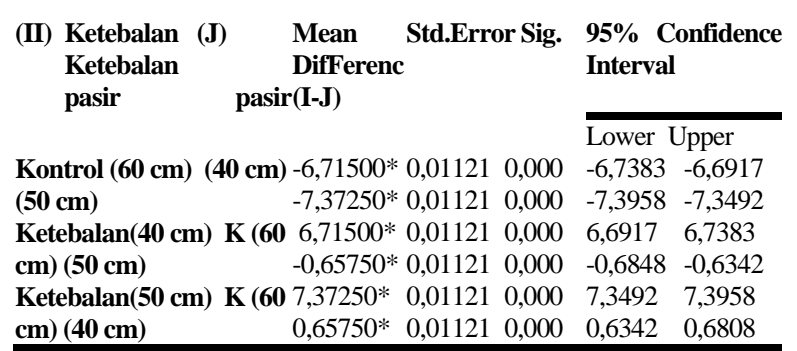

Terlihat pada tabel 8 uji beda ketebalan pasir pada Kontrol $(60 \mathrm{~cm})$ dengan ketebalan pasir $(40 \mathrm{~cm})$ memiliki beda nyata penurunan kadar kekeruhan air sumur gali dengan nilai $\mathrm{p}_{\text {value }}=0,000<\alpha=0,05$, pada $95 \%$-CI (6,7383 - $(-6,6917)$, dengan ketebalan pasir $(50 \mathrm{~cm})$ juga memiliki beda nyata dengan nilai $p_{\text {value }}=0,000>\alpha=0,05$, pada 95\%-CI (-7,3989 - (-7,3492).Perbedaan ketebalan pasir $(40 \mathrm{~cm})$ dengan Kontrol $(60 \mathrm{~cm})$ memiliki beda nyata penurunan kadar kekeruhan air sumur gali dengan nilai $\mathrm{p}_{\text {value }}=0,000<\alpha=0,05$, pada 95\%-CI $(6,6917-6,7383)$. Ketebalan pasir $(40 \mathrm{~cm})$ dengan ketebalan pasir $(50 \mathrm{~cm})$ juga memiliki beda nyata penurunan kadar kekeruhan dengan nilai $\mathrm{p}_{\text {value }}=0,000<\alpha=0,05$, pada 95\%-CI ( 0,6848 - $(-0,6342)$.

Perbedaan ketebalan pasir $(50 \mathrm{~cm})$ dengan Kontrol $(60 \mathrm{~cm})$ memiliki beda nyata penurunan kadar kekeruhan air sumur gali dengan nilai $\mathrm{p}_{\text {value }}=0,000<\alpha=$ 0,05, pada $95 \%$-CI $(7,3492$ - 7,3958). Ketebalan pasir (50 $\mathrm{cm})$ dengan ketebalan pasir $(40 \mathrm{~cm})$ memiliki beda nyata penurunan kadar kekeruhan dengan nilai $\mathrm{p}_{\text {value }}=0,000<\alpha$ $=0,05$, pada $95 \%$-CI $(0,6342-0,6808)$.
3. Uji beda penurunan kadar warna

Tabel 9. Penurunan kadar warna air sumur gali pada perlakuan Terhadap masing-masing ketebalan pasir

\begin{tabular}{llllll}
\hline & $\begin{array}{l}\text { Sum of } \\
\text { Squares }\end{array}$ & Df & $\begin{array}{l}\text { Mean } \\
\text { Square }\end{array}$ & F & Sig. \\
\hline Between & 104,783 & 2 & 52,391 & 45699,565 & 0,000 \\
Groups & 0,024 & 21 & 0,001 & & \\
Within & 104,807 & 23 & & & \\
Group & & & & & \\
Total & & & & & \\
\hline
\end{tabular}

F-hitung pada uji Anova diatas adalah 45699,565 dengan probabilitas yaitu 0,000 , karena $\alpha=0,05$, maka ada perbedaan pengaruh ketebalan pasir pada kontrol $(60 \mathrm{~cm})$, $40 \mathrm{~cm}$ dan $50 \mathrm{~cm}$ sebelum dan sesudah perlakuan terhadap penurunan kadar warna air sumur gali pada saringan pasir dan arang kayu.

Untuk melihat uji beda selanjutnya, pada tabel 10 dapat dilihat lebih jelas seperti pada hasil sebagai berikut :

Tabel 1. Uji beda ketebalan pasir terhadap penurunan kadar warna air sumur gali dalam saringan pasir dan arang kayu

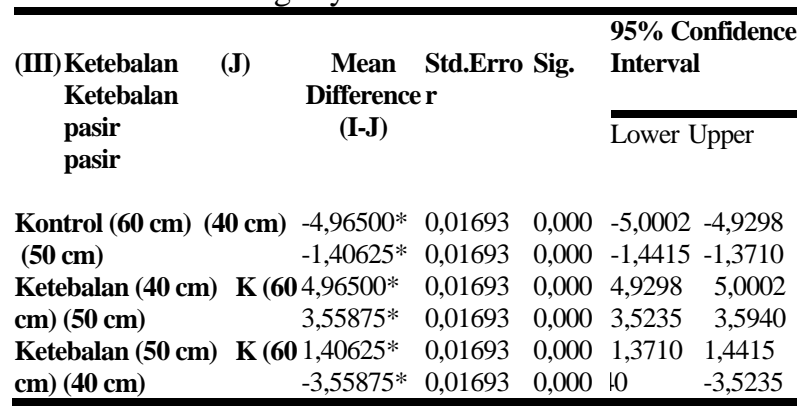

Terlihat pada tabel 10 uji beda ketebalan pasir pada Kontrol $(60 \mathrm{~cm})$ dengan ketebalan pasir $(40 \mathrm{~cm})$ memiliki beda nyata penurunan kadar warna air sumur gali dengan nilai $\mathrm{p}_{\text {value }}=0,000<\alpha=0,05$, pada $95 \%$-CI (5,0002 - $(-4,9298)$, dengan ketebalan pasir $(50 \mathrm{~cm})$ juga memiliki beda nyata penurunan kadar warna dengan nilai $\mathrm{p}_{\text {value }}=0,000<\alpha=0,05$, pada $95 \%$-CI $(-1,4415-(-$ 1,3710).

Perbedaan ketebalan pasir $(40 \mathrm{~cm})$ dengan Kontrol $(60 \mathrm{~cm})$ memiliki beda nyata penurunan kadar warna air sumur gali dengan nilai $\mathrm{p}_{\text {value }}=0,000<\alpha=0,05$, pada $95 \%$-CI $(4,9298$ - 5,0002). Ketebalan pasir $(40 \mathrm{~cm})$ dengan ketebalan pasir $(50 \mathrm{~cm})$ juga memiliki beda nyata penurunan kadar warna dengan nilai $\mathrm{p}_{\text {value }}=0,000<\alpha=$ 0,05, pada 95\%-CI ( 3,5235-3,5940).

Perbedaan ketebalan pasir $(50 \mathrm{~cm})$ dengan Kontrol $(60 \mathrm{~cm})$ memiliki beda nyata penurunan kadar warna air sumur gali dengan nilai $\mathrm{p}_{\text {value }}=0,00<\alpha=0,05$, pada $95 \%$ CI $(1,3710$ - 1,4415). Ketebalan pasir $(50 \mathrm{~cm})$ dengan ketebalan pasir $(40 \mathrm{~cm})$ memiliki beda nyata penurunan kadar warna dengan nilai $\mathrm{p}_{\text {value }}=0,000<\alpha=0,05$, pada $95 \%$-CI $(-3,5940-(-3,5235)$. 
Kesimpulan

1. Ketebalan pasir $40 \mathrm{~cm}$ dan $50 \mathrm{~cm}$ dalam media saringan pasir dan arang kayu dapat menurunkan kadar besi $(\mathrm{Fe})$ yaitu $89,06 \%$ dan $92,82 \%$.

2. Ada pengaruh ketebalan pasir $40 \mathrm{~cm}, 50 \mathrm{~cm}$ dalam media saringan pasir dan arang kayu ( - $_{\text {value }}=0,000<\alpha$ $=0,05)$ terhadap penurunan kadar besi $(\mathrm{Fe})$ air sumur gali.

3. Ada pengaruh ketebalan pasir $40 \mathrm{~cm}, 50 \mathrm{~cm}$ dalam media saringan pasir dan arang kayu $\left(\mathrm{p}_{\text {-value }}=0,000<\alpha\right.$ $=0,05)$ terhadap penurunan kadar kekeruhan air sumur gali.

4. Ada pengaruh ketebalan pasir $40 \mathrm{~cm}, 50 \mathrm{~cm}$ dalam media saringan pasir dan arang kayu ( - $_{\text {value }}=0,000<\alpha$ $=0,05$ ) terhadap penurunan kadar warna air sumur gali.

Saran

1. Masyarakat di daerah kota Medan yang memiliki sumur gali apabila airnya mengandung kadar besi $(\mathrm{Fe})$ tidak memenuhi syarat kesehatan $(>1,0 \mathrm{mg} / \mathrm{l})$, agar air sumur gali memenuhi syarat kesehatan dapat menggunakan saringan pasir dan arang kayu dengan ketebalan pasir minimal $\geq 50 \mathrm{~cm}$.

2. Petugas Puskesmas/Dinas Kesehatan Kota Medan dapat memberikan penyuluhan kepada masyarakat untuk mengatasi air sumur gali yang mengandung kadar besi $(\mathrm{Fe})$ dengan menggunakan media saringan pasir dan arang kayu dengan ketebalan pasir minimal $50 \mathrm{~cm}$.

3. Penelitian selanjutnya perlu melakukan uji coba untuk menurunkan kekeruhan dan warna air sumur gali agar sesuai dengan standar kualitas air minum perlu penambahan ketebalan pasir $\geq 70 \mathrm{~cm}$ dalam media saringan pasir dan arang kayu.

\section{Daftar Pustaka}

Aimyaya, 2013; Saringan pasir arang, http://nanosmart filter.com, diakses tanggal 17 Nopember 2013.

Badan Pengkajian dan Penerapan Teknologi, 1999; Kesehatan Masyarakat dan Teknologi Peningkatan Kualitas air, Direktorat TeknologiLingkungan Deputi Bidang Teknologi Informasi, Energi, Material dan Lingkungan, Jakarta.

Boyd, C.E, 1988; Water Quality in warm water Fish Ponds, Fourth Printing, Auburn University Agricultural Experiment Station, Alabama, USA.

Chandar Budiman, 2006; Pengantar Kesehatan Lingkungan, Penerbit buku Kedokteran EGC.

Depkes RI ;1990; Permenkes RI, No: 416/ Menkes/SK/XI/1990 Tentang Syarat-syarat dan pengawasan kualitas air bersih, Jakarta.
;2010; Riset Kesehatan Dasar Tentang Penyediaan Air Bersih, Jakarta

Effendi, H, 2003; Telaah Kualitas Air bagi Pengelolaan Sumber daya Lingkungan Perairan, Kanisius, Yogyakarta.

Hannafiah Kemas Ali, 2003; Rancangan Percobaan Teori \& Aplikasi, cetakan 8, PT.Raja Grafindo Persada, Jakarta.

Herman, Hermawan; 2006; Pengaruh ketebalan saringan pasir lambat model IOS-SF terhadap penurunan Total Coli-form dan Coli-tinja sebagai dampak penurunan kekeruhan pada air kolam sebagai air bersih, Thesis, Undip, Semarang.

Huisman (1974); Slow Sand Filter, University of Technology, Netherlands.

Kusnaedi, 2006; Mengolah air gambut dan Air Kotor untuk minum, Penebar, Swadaya, Jakarta. --, 1998; Pengolahan air, Bagian Peneribitan PT.Gramedia Pustaka Utama, Jakarta.

Moore, J.W, 1991; Inorganic Contaminants of Surface Water, Springer-Verlag New York.

M.Ridwan Saifudin dan Dwi Astuti,2005; Kombinasi media filter untuk menurunkan kadar besi (Fe), Jurnal Penelitian Sains dan Teknologi, Vol.6 No.1 Tahun 2005 : 49 - 64.

Meilita, T, 2007; Arang Aktif (Pengenalan dan proses pembuatannya), http://library.usu.ac.id/Arang Aktif, diakses tanggal 8 Nopember 2013.

Nusa, Idaman Said, 1999; Kesehatan Masyarakat dan Teknologi Kualitas Air , Peneribit Direktorat Teknologi Lingkungan,Deputi Bidang TIEML,BPPT, Jakarta.

Safira Astari, Rofiq Iqbal; Realibility of Slow Sand Filter for Water Treatment; Prodi Teknik Lingkungan Fakultas Teknik Sipil dan Lingkungan ITBBandung.

Satrio, Wibowo, Teknik Penjernihan Air, http://aimyaya.com/id, diakses tanggal 8 Nopember 2013.

Slamet Juli Sumirat, 2004; Kesehatan Lingkungan, Gajah Mada University Press, Yogyakarta.

Sugandi,E.Sugiarto,1994; Rancangan Percobaan Teori dan Analisis, Andi Offset, Yogyakarta.

Suyono, 1993; Pengelolaan Sumber Daya Air, Fakultas Geografi Universitas Gajah Mada, Yogyakarta.

V.Darsono dan Teguh Sutomo, 2002; Pengaruh diameter dan ketebalan pasir dalam Saringan pasir lambat terhadap penurunan kadar (Fe), Jurnal Teknologi Industri, Vol.VI.No.4, Oktober 2002 : 213-224. 